\title{
THE CLAVICLE OF NEWBORN DOGS
}

\author{
H. ČERNÝ and S. ČIŽINAUSKAS
}

Department of Anatomy, Histology and Embryology, Faculty of Veterinary Medicine, University of Veterinary and Pharmaceutical Sciences, 61242 Brno

Received December 15, 1994

Accepted May 30, 1995

\begin{abstract}
Č e r n ý H., S. Či ž̌ i n a u s k a s: The Clavicle of Newborn Dogs. Acta vet. Brno 1995, 64: 139-145.

The morphology, topography and structure of the clavicle and its adnexa, forming together the clavicular complex, were investigated in 21 newborn dogs of both sexes and various breeds by dissection, radiography and histological techniques.

The reduced clavicle, 1 to $2 \mathrm{~mm}$ in size, was oval in most cases. Horseshoe-shaped and annular clavicles were less frequent.

The clavicle was located outside the clavicular intersection being linked with it by a fascicle of collagenous fibres. A similar fascicle linked the clavicle with the caudal margin of the scapula. No links of the clavicle with the sternum or the perimysium of the pectoral muscles were observed in the early postnatal period.

The histological pattern was typical of desmogenic ossification. Osteoid and osseous trabeculae formed an incoherent cortical surface lamella and the formation of a cavity was evident in the centre of the clavicle. The osseous trabeculae aimed radially forming an anastomosing network. The surface of the clavicle was covered by a coherent layer of connective tissue with arranged fascicles of collagenous fibres which, on both ends of the clavicle, passed continuously into fibrous fascicles connecting the clavicle with the surrounding structures and forming together a functional unit.

An oval basis of an embryonic cartilage, which we considered to be the preclavium, was observed at the sternal end of the clavicle in more than one half of the dogs. The function of the markedly reduced canine clavicle in the early postnatal period, in which the formation of the associated structures is not yet influenced by locomotion, is discussed. We assume that some of the links joining the clavicle with the adjacent structures develop only after birth in dependence on the locomotion.
\end{abstract}

Newborn dog, early postnatal ontogenesis, clavicle, function, morphology, ossification

The clavicle is one of the components of the bone skeleton of the pectoral girdle connecting the scapula with the sternum. Its primary function is to reinforce the moving extremity.

In most mammalian species, the clavicle develops as an important element of the skeleton. On the other hand, it is subject to regression in other species and its function has become limited with the advancing adaptation. The phylogenetic transformation of the skeleton of the pectoral girdle is causally linked with the development of locomotion. The accelerating locomotion and the increased motility of mammals were associated with the turning of both limbs towards the trunk. The limbs aim ventrally and the trunk is hung on them.

The change of the overall arrangement of the mammalian skeleton was accompanied by a reduction of the ventral part of the pectoral girdle skeleton consisting of the coracoid and the clavicle, while the dorsal part, i.e. the scapula, has developed fully. The supportive function of the ventral part of the mammalian pectoral girdle skeleton has been taken on by a single bone - the clavicle. The coracoid has disappeared as a separate bone and persists as a vestigial prominence (processus coracoideus) of the scapula.

The advancing regressive development has affected the clavicle which is found as a markedly reduced and very small bone in some mammalian species and has become extinct in others. Various degrees of the clavicular regression can be observed in Ungulata, Carnivora, Cetacea, and Sirenia (S t a r c k 1979). 
There is agreement in literature as to the data on the size, shape and development of the canine clavicle. The clavicle arises by desmogenic ossification and, in adult dogs, this flat bone has a diameter of $5 \mathrm{~mm}$ and the maximum dimension of $13 \mathrm{~mm}$ (D o $\mathrm{n}$ a $\mathrm{t}$ 1979; $\mathrm{M} \mathrm{c} \mathrm{C}$ ar t h y and W o od 1988).

The data on the topography of the canine clavicle are controversial. Early papers ( $\mathrm{N}$ a u k 1938), but also recently published books ( $\mathrm{E} v \mathrm{a} \mathrm{n} \mathrm{s} 1993$ ), regard the clavicle as a structural part of the fibrous intersection (intersectio clavicularis) within the brachiocephalic muscle.

On the other hand, D o $\mathrm{n}$ a t (1971) and M c C a r th y and W o o d (1988) locate the vestigial clavicle outside the intersectio clavicularis affirming that the two structures are connected by a fascicle of collagenous fibres.

Radiologic examinations done by Mc C a r t h y and W o o d (1988) have demonstrated the presence of the clavicle in $96 \%$ of the dogs. No radiodense structures could be detected in the remaining animals.

The development of the canine clavicle begins by desmogenic ossification from a single ossification area at an early stage of ontogeny. The first signs of ossification are evident on Day 28 of the ontogenic development ( $\mathrm{E} v$ a $\mathrm{n}$ s 1993). The ossification of the clavicle from a single ossification area was also reported in earlier papers. The only exceptions were the papers by $\mathrm{S} \mathrm{c}$ h a e f f e r $(1932,1934)$. Although confirming the known data on the ossification of the clavicle, he described three ossification areas in a 28-day-old canine fetus.

An interesting finding concerning the regression of the clavicle was published by $\mathrm{S} \mathrm{c} h$ a e f f e $\mathrm{r}$ (1938) who affirmed that the regression began already during the prenatal ontogeny and supported this view by the finding in a $120-\mathrm{mm}$-long fetus of a $3.5 \mathrm{~mm}$-long clavicle which diminished to approximately $2 \mathrm{~mm}$ at the time of parturition.

\section{Materials and Methods}

The shape, size and structure of the clavicle and its adnexa were investigated by anatomic dissection, radiography and histological examination in 21 newborn dogs of both sexes and various breeds.

The 42 humeral joints were dissected from the craniomedial aspect which we considered the most suitable for this purpose.

Radiologic examinations were done in the dorsoventral projection at the maximal abduction of the extremity in five newborn dogs. For the in toto radiography, both extremities were ablated in a way saving intact the connection of the clavicle with the intersection and thus with the brachiocephalic muscle. The ablated limb with the clavicle was radiographed in the lateromedial projection using the Perlux film and the intesifying screen at the exposure values of $42 \mathrm{kV}, 50 \mathrm{~mA}, 0.03 \mathrm{~s}$.

Samples involving the vestigial clavicle and the adjacent tissues were collected for light microscopy. The samples were fixed in $10 \%$ neutral formalin, dehydrated and embedded into Paraplast. Seven $\mu \mathrm{m}$ thick sections were stained with $\mathrm{HE}$, after Goldner and with alcian blue followed by the mixture of Ponceau $2 \mathrm{R}$ and acid fuchsin.

\section{Results}

The markedly reduced clavicle was found bilaterally in all the 21 newborn dogs as a bone 1 to $2 \mathrm{~mm}$ in size. The sizes were proportional to the breed-specific body sizes and masses.

At this stage of ontogeny, the shape of the clavicle is not yet stabilized. The clavicles were oval in most dogs, while the horseshoe shape was less frequent and annular clavicles with central holes were observed in four animals.

The clavicle was regularly found caudomedially from the intersectio clavicularis being connected syndesmotically with the tendineous intersection separating, within the brachiocephalic muscle, the cleidocephalic from the cleidobrachial muscle. Its position was invariably outside the intramuscular fibrous band. 
The clavicle is embedded in the connective tissue filling the intermuscular space. Around the clavicle, bundles of collagenous fibres could be observed which converged into thin and flat fibrous bands connecting the reduced clavicle with the surrounding structures. A short, approx. 1-mm-wide fibrous band connecting the clavicle with the intersectio clavicularis arises from the cranial (sternal) end. Another band of the same width, but much longer, arises from the caudal (scapular) end of the clavicle and extends caudodorsally towards the caudal scapular angle to radiate there into the subscapular fascia and thus to connect the clavicle with the scapula.

Unlike the authors who, in adult dogs, described the direct link between the clavicle and the sternum or the perimysium of the pectoral muscles provided by separate collagenous bundles, we were not able to detect such structures in the newborn dogs.

The topographic position of the clavicle has been confirmed by radiologic findings. At the early stage of postnatal ontogeny, the clavicle is visible in radiographs as a radiodense spot with a diameter of 1 to $2 \mathrm{~mm}$ located cranially from the humeral joint in the contour of the brachiocephalic muscle.

Light microscopic investigations of tissue sections yielded a pattern typical of the desmal ossification. The surface of the mineralized clavicular tissue is covered by a continuous fibrous layer with arranged fascicles of collagenous fibres passing fluently into the fibrous fascicles connecting the clavicle with the surrounding tissues at its sternal and scapular ends.

The osseous tissue of the clavicle, that has arisen by desmogenic ossification, is arranged into bony trabeculae without forming solid surface lamellae. The apposition of additional bony trabeculae onto the incoherent cortical lamella can be seen occasionally. The large intertrabecular spaces are filled by connective tissue communicating, at the surface, with the fibrous blastema.

While the desmogenic ossification at the surface results in the formation of new osteoid or osseous trabeculae, a central cavity filled with connective tissue arises in the middle of the clavicle. In some cases, the cavity is responsible for the atypical annular shape of the clavicle. Although the trabeculae are arranged into an anastomosing network, most of them aim radially into the centre of the clavicle.

In a tangential cut, the horseshoe-shaped clavicle appears as a duplex structure with its mineralized parts linked on both ends by connective tissue.

An oval grround matrix was observed at the sternal end of the clavicle in more than one half of the dogs under study. The structure was entirely separated from the osteoid or osseous tissue of the clavicular surface by a layer of connective tissue. A condensation of the connective tissue on the surface of the cartilage gives rise to fibrous blastema containing precursor cells which differentiate into chondroblasts during chondrogeny. The differentiation is apparent on the surface of the cartilage which shows the pattern of an embryonic cartilage. The chondrocytes are less differentiated; in fact, they are chondroblasts secreting the cartilagineous matrix. The cells are located in narrow lacunas in the matrix. Larger lacunas and, quite exceptionally, the rise of isogenic groups of cells can be observed in the central part of the cartilage.

No direct relationship exists between the sizes of the separate cartilagineous structures and of the clavicle.

\section{Discussion}

The considerable reduction of the clavicle is the result of the regressive development of the pectoral girdle skeleton. The extinction of the original articulations with the sternum and the scapula has been associated with a loss of the static and stabilizing functions of the clavicle which has become a significant kinetic element. Recent data associate the function 
of the clavicle with that of the surrounding structures and $\mathrm{Mc} \mathrm{C}$ a r th $\mathrm{y}$ and $\mathrm{W}$ o o d (1988) have proposed the term clavicular complex which, without doubt, gives a more accurate picture of the clavicle itself. A review of the current knowledge has highlighted the following functions of the clavicular complex:

- stabilization of the proximal part of the extremity during locomotion;

- adjustment of the position of the brachiocephalic muscle during muscular contraction, provided by the junction of the clavicle with the clavicular intersection; the proximal part of this muscle, known as the cleidocephalic muscle, moves the humeral joint cranially, while the caudal part - the cleidobrachial muscle, is the extensor of this joint; the clavicle is an important point in the kinetics of the humeral joint and thereby in the overall movement of the foreleg, particularly in its abduction and cranial and caudal movements;

- adjustment of the position of the moving extremity including the protection of the brachial plexus and the axillar blood vessels from mechanical damage.

$\mathrm{M} \mathrm{c} \mathrm{C} \mathrm{a} \mathrm{r} \mathrm{th} \mathrm{y} \mathrm{and} \mathrm{W} \mathrm{o} \mathrm{o} \mathrm{d} \mathrm{(1988)} \mathrm{compared} \mathrm{the} \mathrm{function} \mathrm{of} \mathrm{the} \mathrm{canine} \mathrm{clavicle} \mathrm{and} \mathrm{its}$ adnexa to that of the cartilago iliopubica located in the origin of the pectineus muscle. This cartilage is subject to ossification in $10 \%$ of dogs and, together with its fibrous attachments, resembles the clavicle.

D o n a t (1971) compared morphological and functional aspects of the kinetic role of the canine and feline clavicles including their junctions with the adjacent tissues. While in cats the clavicle is invested in the muscles serving for their attachment, the canine clavicle is connected with its adnexa only syndesmotically through collagenous fibres originating from the clavicle and linking it with the intersectio clavicularis, the scapula, the sternum and the perimysium of the pectoral muscles. According to published data, the clavicle of adults is connected with the sternum and the pectoral muscles only through thin bundles of fibrous tissue - a junction which is apparently much weaker than that with the brachiocephalic muscle or the scapula.

No separate bundles of collagenous fibres linking the rudimentary clavicle with the sternum or the pectoral muscles were observed in our investigations of newborn dogs. We presume that the junction is formed only later as a response to the development of locomotion influencing the arrangement of the adjacent connective tissue. Also important may be the increase in body weight, particularly the weight of the trunk which is hung on the pectoral girdle. We assume that this increase can influence the formation of the junction of the clavicle with the ventral parts of the chest.

If our presumption is correct, the decision to investigate the clavicular complex in neonates has been justified. The locomotor mechanisms are not yet fully developed at the early stage of ontogeny and the information gained in our investigations has been a good basis for further studies.

In neonates, the shape of the clavicle arising by desmogenic ossification is not unambiguously defined. Oval clavicles prevail clearly over the hook-shaped and horseshoeshaped ones. The annular clavicles found in our investigations are apparently another morphological variant that has not been described hitherto. The shape of the clavicle changes during ontogeny. Its growth goes on in the postnatal period and the original hook-shaped bone, that is typical of the early developmental stage, changes into a thin and flat one (E v a n s 1993). According to our observations, the clavicle retains the shape assumed during the early ontogeny in some cases. The variety of shapes found in the neonatal dogs, or described by other authors in adults, is suggestive of an instability in shape as a result of the marked reduction of the clavicle. D o n a t (1971) described the clavicle as a hook-shaped bone, while $\mathrm{M} \mathrm{c} \mathrm{C} \mathrm{a} \mathrm{r} \mathrm{t} \mathrm{h} \mathrm{y} \mathrm{and} \mathrm{W} \mathrm{o} \mathrm{o} \mathrm{d} \mathrm{(1988)} \mathrm{as} \mathrm{a} \mathrm{triangular} \mathrm{or} \mathrm{a} \mathrm{trapezoidal} \mathrm{one.}$

The microscopic pattern of the clavicle in the early postnatal period is typical of 
desmogenic ossification. The ossification sets in already during the prenatal period. In dogs, a single ossification area is evident from post-conception Day 28. Dog is an example of species with markedly reduced clavicles. On the other hand, the development of the clavicle is different from that of other bones in the species in which this bone has become a full-value component of the pectoral girdle skeleton. Thus, for instance, the shaft of the human clavicle arises by desmogenic ossification from two ossification areas and both of its ends by chondrogenic ossification from cartilagineous bases (A $\mathrm{r}$ e $\mathrm{y}$ 1971). If the mammalian clavicle arises by both desmogenic and chondrogenic ossifications, it is not comparable with the thoracal bone of lower vertebrates as a part of the dermal skeleton of the girdle arising by desmogenic ossification only.

$\mathrm{N} \mathrm{a} \mathrm{u} \mathrm{k} \mathrm{(1929)} \mathrm{and} \mathrm{F} \mathrm{u} \mathrm{c} \mathrm{h} \mathrm{s} \mathrm{(1934)} \mathrm{explain} \mathrm{the} \mathrm{origin} \mathrm{of} \mathrm{the} \mathrm{clavicle} \mathrm{in} \mathrm{placental} \mathrm{mammals}$ by the union of the thoracal bone with the procoracoid cartilage. This hypothesis is not generally applicable and does not conform fully with the phylogenetic continuity, because the rudimentary coracoid was demonstrated without any apparent link with the development of the clavicle.

In Eutheria, the original endoskeletal bases of the ventral part of the pectoral girdle emerge in the ongoing development along with the development of the scapula and not in connexion with the development of the clavicle. The bases associate with the scapula and the separate ossification area in the coracoid process corresponds to the original metacoracoid. The second separate ossification area at the basis of the coracoid process can be regarded as the procoracoid in Monotremata (S t a r c k 1979).

Therefore, the association of the dermal and the endoskeletal bases of the clavicle, as reported in earlier literature, appears as unjustified from the morphological point of view. In addition to the rejection of this view, $\mathrm{S} \mathrm{t}$ a r c k (1979) drew attention to the fact that the clavicular cartilage never joins with the primordial cartilagineous basis of the pectoral girdle skeleton, emerging much later as a secondary cartilage lacking any morphological or functional links with the pectoral girdle skeleton.

Referring to comparative phylogenetic connexions, $\mathrm{S}$ t a r ck regards the clavicle as a bone arising by desmogenic ossification along with the ossification of the secondary cartilage.

In more than one half of the dogs under study, histological examinations revealed the presence of a separate, non-ossifying oval cartilagineous basis at the sternal end of the rudimentary clavicle. This finding is conformable with the views of $\mathrm{Ev}$ ans and $\mathrm{L}$ a $\mathrm{h}$ u $\mathrm{nta}$ (1971) and E v a n s (1993) that both osseous and cartilagineous tissues participate in the structure of the clavicle.

The explanation of the existence of the canine clavicular cartilage is somewhat more complex. Its occurrence in neonatal dogs is irregular; the size of the basis is individually variable; the cartilage does not ossify and lacks any structural link with the osseous tissue of the vestigial clavicle. We hold to the view that this structure is no secondary clavicular cartilage, but rather the preclavium referred to in the review by S t a r c k (1979). The preclavium can be occasionally found during ontogeny as a cartilage at the sternal end of the clavicle. The ossification of the latter was described in some Insectivora. The preclavium is occasionally accompanied by a smaller cartilagineous basis; both the bases are then regarded as the remains of the ventral cartilagineous skeleton of the pectoral girdle. St a r c k assumes that the human preclavium is a structure homologous with the intraarticular disc within the sterno-clavicular joint. The structural reduction of the clavicle, resulting in a variety of shapes in adult dogs, is suggestive of a non-stabilized regressive and individually variable process. The ontogeny of the reduced clavicle reflects not only the general biogenetic regularity including the recapitulation of phylogeny, but also the adaptation to the changing conditions of life associated particularly with the accelerating locomotion. 


\section{Klavikula novorozeného psa}

U 21 novorozených psů obojího pohlaví a různého plemene do 24 hodin post natum jsme preparační, rentgenologickou a histologickou metodou sledovali morfologii, topografii a mikroskopickou anatomii klavikuly včetně její asociované struktury.

Redukovaná klavikula o rozměru 1-2 mm je většinou oválného tvaru, podkovovitý a anulární tvar se vyskytuje méně často.

Topograficky se klavikula nachází mimo intersectio clavicularis, se kterým se spojuje vazivovým pruhem tvořeným $\mathrm{z}$ orientovaných kolagenních vláken, který spojuje sternální konec klavikuly a šlašitý vpis. Stejně výrazné je i spojení lopatkového konce klavikuly $\mathrm{s}$ kaudálním úhlem lopatky. $\mathrm{V}$ raném postnatálním období jsme nepozorovali spojení klavikuly se sternem a s perimysiem prsních svalů, jak je popisováno u adultních jedinců.

$\mathrm{V}$ tkáňových řezech klavikulou je patrná desmogenní osifikace původního mezenchymového blastému s tvorbou nesouvislé povrchové kostní kortikální lamely, $\mathrm{v}$ centru osteoidních a kostních trámců. Trámce probíhají převážně radiálním směrem a tvơ̌í anastomozující sít, zatímco ve středové cásti osifikujícího blastému je patrné formování centrální dutiny.

Povrch klavikuly kryje v souvislé vrstvě vazivová tkáň, která na obou koncích klavikuly přechází v podobě vazivových pruhů do okolních útvarů, s nimiž tvoří jeden celek klavikulární komplex.

Více než $\mathrm{v}$ polovině př́padů jsme $\mathrm{v}$ mikroskopickém obrazu pozorovali na sternálním konci klavikuly oválný chrupavčitý základ embryonální chrupavky, který byl od klavikuly separován vrstvou vaziva a který považujeme za preklavium.

V období do 24 hodin po narození mají neonáti výrazně omezenou pohyblivost, která je, podle našeho názoru, důsledkem toho, že se nám nepodařilo prokázat př́mé vazivové spojení klavikuly se sternem a prsními svaly. Domníváme se, že některá spojení klavikuly s okolím se tvơ̌i až postnatálně v závislosti na rozvoji pohybu.

\section{Acknowledgement}

The authors wish to thank Mrs. A. Hloušková for her technical assistance and for making the histological preparations, and Mr. K. Tomša for his collaboration in radiography.

\section{References}

AREY L. B. 1966: Developmental Anatomy. W.B. Saunders Co., Philadelphia, London, 7th Ed., 695 p.

DONAT K. 1971: Die Fixierung der Clavicula bei Katze und Hund. Anat. Anz. 128:365-374

EVANS E. H., LAHUNTA A. 1971: Guide to the dissection of the dog. W.B. Saunders Co., Philadelphia, London, Toronto, $291 \mathrm{p}$.

EVANS E. H. 1993: Miller's Anatomy of the Dog. 3th Ed. W.B. Saunders Co., Philadelphia, London, Toronto, Montreal, Sydney, Tokyo, 1113 p.

FUCHS H. E. 1934: Beiträge zur Entwickulngsgeschichte und vergleichenden Anatomie des Brustschultergürtels der Wirbeltiere. Morph. Jb. 74:380

MCCARTHY P. H., WOOD A. K. 1988: Anatomic and radiologic observations of the clavicle of adult dogs. Am. J. Vet. Res. 49:956-959

MCCARTHY P. H., WOOD A. K. 1985: Anatomical and radiological studies of the iliopubic cartilage in adult Greyhounds. Anat. Histol. Embryol. 15:73-79

MILLER M. E., CHRISTENSEN G. C., EVANS H. E. 1964: Anatomy of the dog. W.B. Saunders Co., Philadelphia, London, $948 \mathrm{p}$.

NAUK E. Th. 1929: Beiträge zur Kenntnis des Skeletts der paarige Gliedmassen der Wirbeltiere.VI. Das Schlüssel der Säugetiere und die Coracoprocoracoidplatte. Morph. Jb. 62:20

NAUK E. Th. 1938: Extremitätenskelett der Tetrapoden.In: BOLK L.E., GOPPERT E. , KALLIUS E., LUBOSCH W. Handbuch der vergleichenden Anatomie der Wirbeltiere. Bd. 5, Urban und Schwarzenberg, Berlin, Wien

RAVELLI A. 1955: Versuch einer entwicklungsgeschichtlichen Deutung bestimmter Einzelheiten am Schlüsselbein und seinen Verbindung. Zschr. Anat. Entw. gesch. 118:343 
ROMER A. S., PARSONS T. S. 1983: Vergleichende Anatomie der Wirbeltiere. Paul Parey, Hamburg, Berlin, $24 \mathrm{p}$.

SCHAFFER H. 1934: Die Ossifikationsvorgänge im Gliedmassenskelett des Hundes. Morph. Jb. 74:472-514

SCHNORR B. 1985: Embryologie der Haustiere. Enke Verlag, Stuttgart, 244 p.

STARCK D. 1979: Vergleichende Anatomie der Wirbeltiere auf evolutionsbiologischer Grundlage. Bd. 2. Das Skelettsystem. Springer Verlag, Berlin, Heidelberg, New York, 776 p. 
Plate I.

Černý H., Čižinauskas S.: The Clavicle... pp. 139-145.

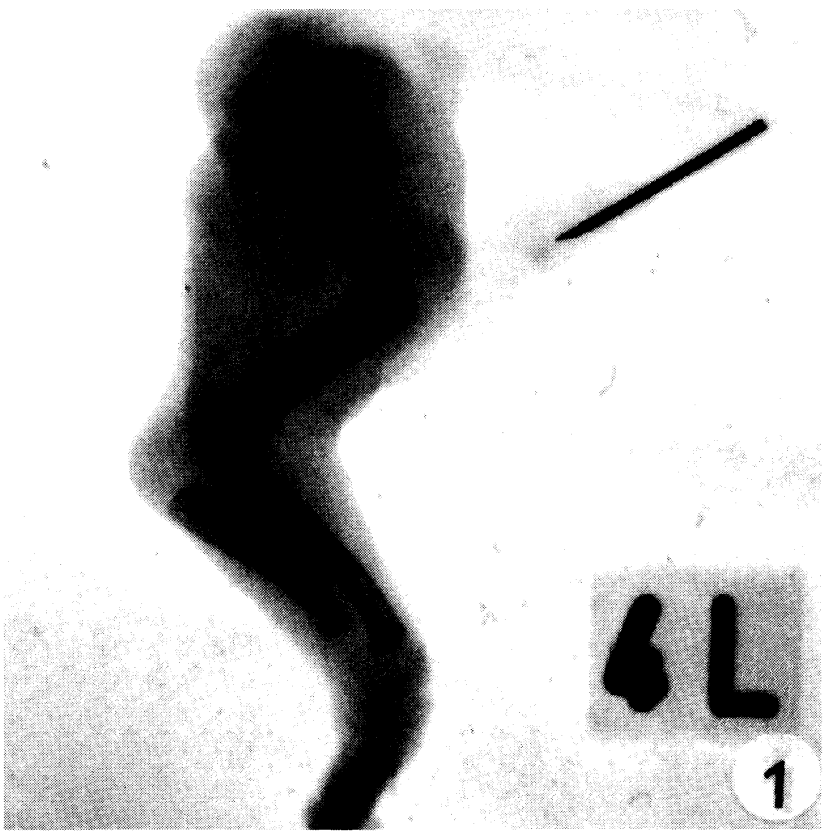

Fig. 1: Radiograph of the right foreleg. Magn. 1:1; the clavicle is visible as a minute radiodense point (arrow).

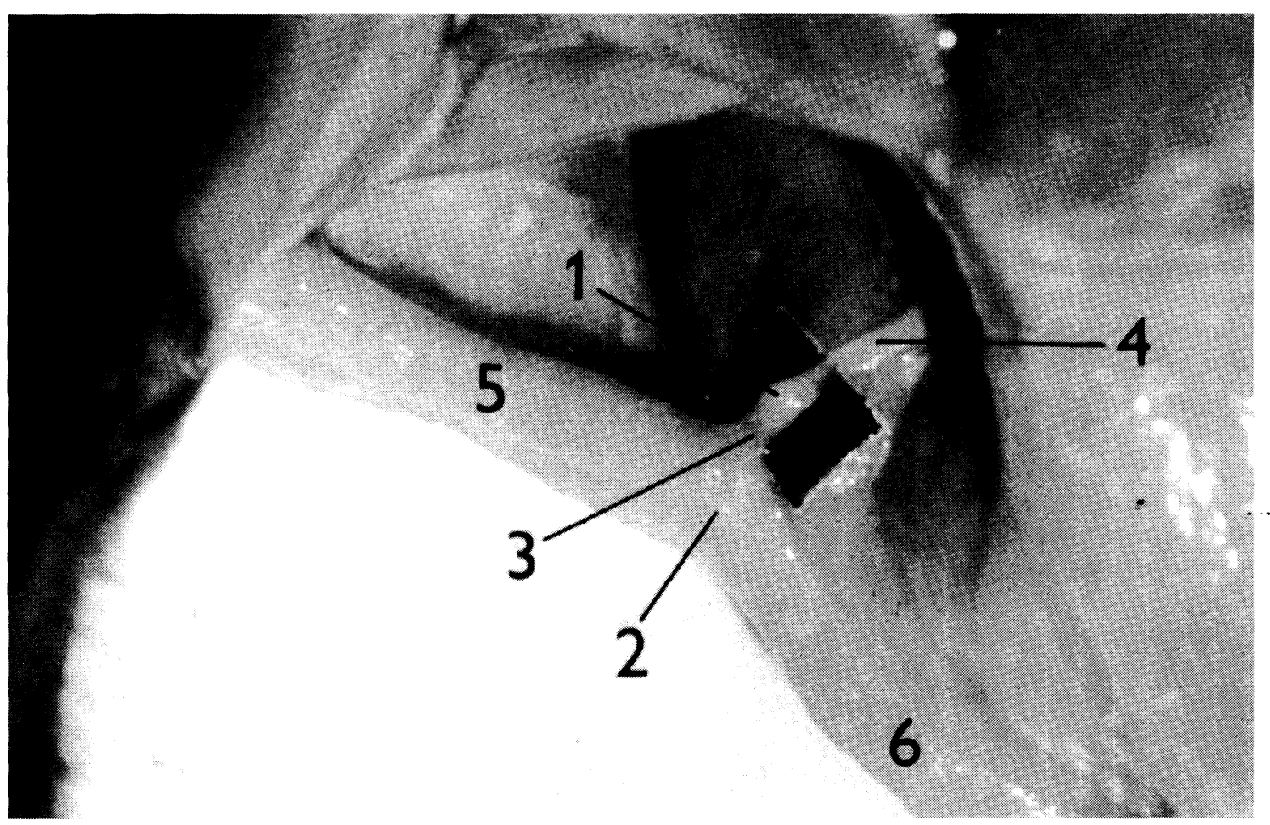

Fig. 2: Topography of the clavicle and its junction with the adjacent structures. $x 2.5 .1$ - clavicle, 2 - intersectio clavicularis, 3 - syndesmotic junction of the clavicle with intersectio clavicularis, 4 - junction of the clavicle with the caudal margin of the scapula, 5 - cleidocephalic muscle, 6 - cleidobrachial muscle (brachiocephalic muscle), 7 - supraspinatus muscle 
Plate II.

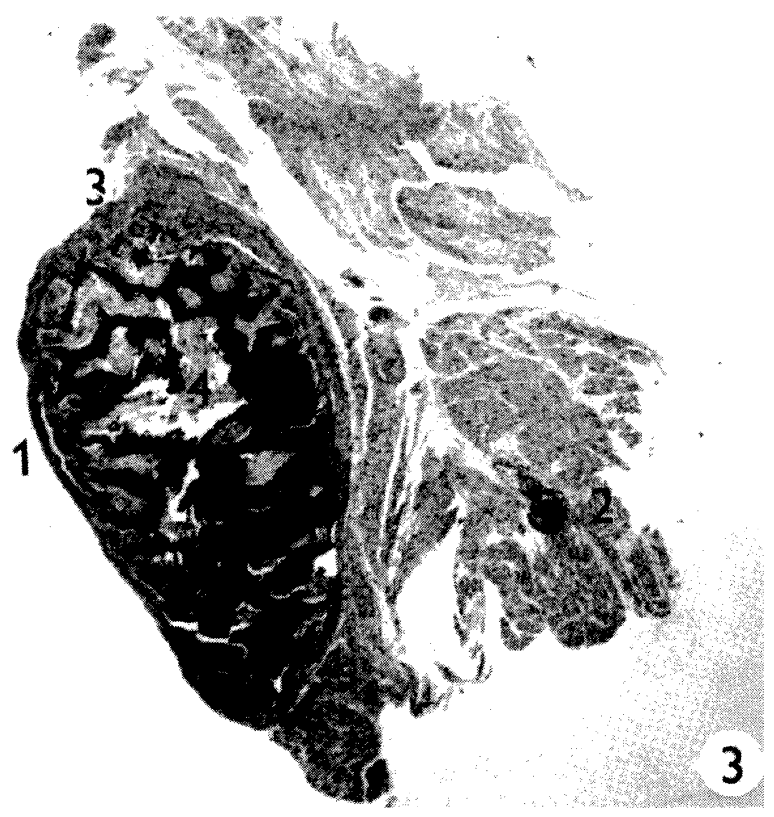

Fig. 3: Microscopical pattern of the clavicle. x 401 - sternal end of the clavicle, 2 - scapular end of the clavicle, 3 - fibrous capsule with origins of fibres providing the junction with intersectio clavicularis, 4 - fibrous tissue of the clavicle.

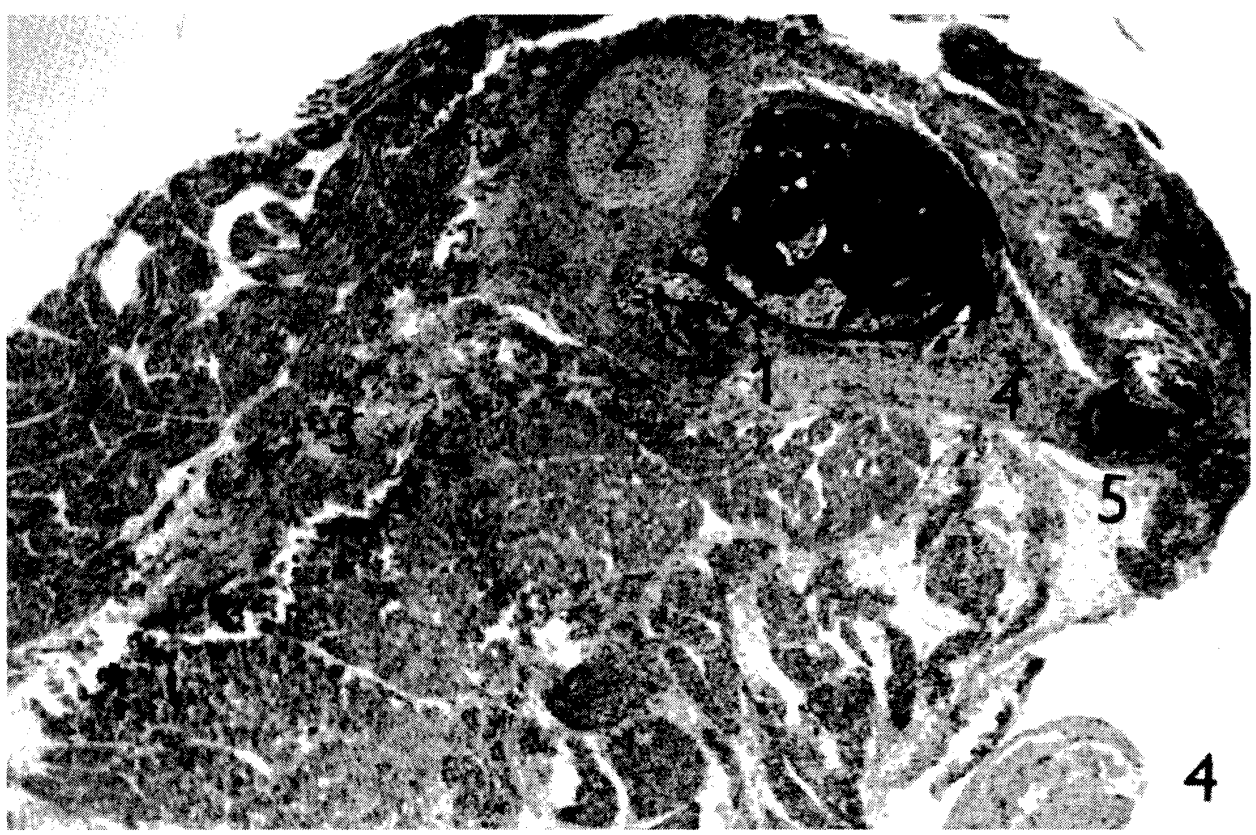

Fig. 4: Cut through a horseshoe-shaped clavicle. $x$ 40. 1 - sternal end, 2 - preclavium, 3 - intersectio clavicularis joined with the clavicle, 4 - fibrous tissue of the clavicle, 5 - scapular end. 


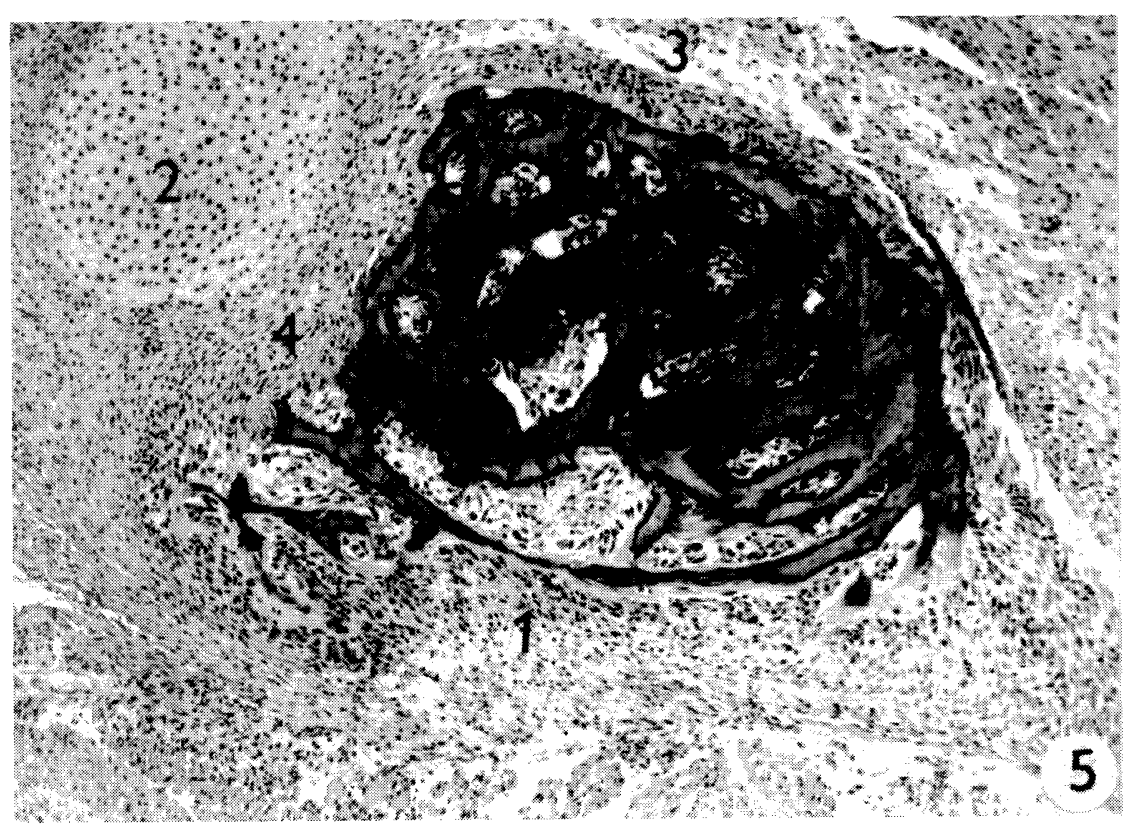

Fig. 5: Sternal end of the clavicle. x 100. 1 - incoherent cortical osseous lamella, 2 - preclavium, 3 - fibrous surface layer, 4 - fibrous band separating the preclavium from the mineralized tissue of the clavicle.

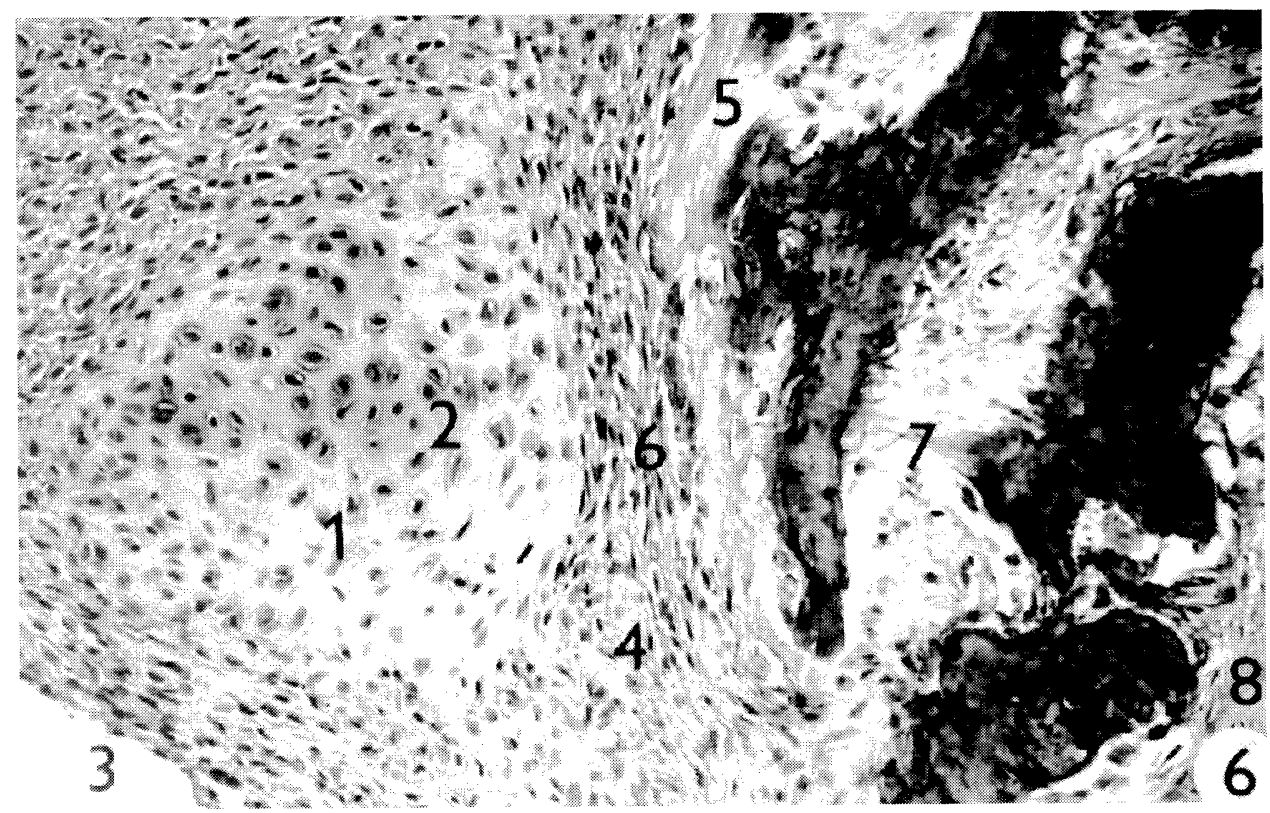

Fig. 6: Preclavium and its topographic relation to the clavicle. x 250.1 - preclavium, 2 - solitary isogeneic group, 3 - fibrous layer with precursor cells, 4 - chondrification from cells of the surface layer, 5 - osteoid tissue of a clavicular trabecula, 6 - fibrous layer separating preclavium from the clavicle, 7 - intertrabecular space, 8 - connective tissue of the central cavity. 
Plate IV.

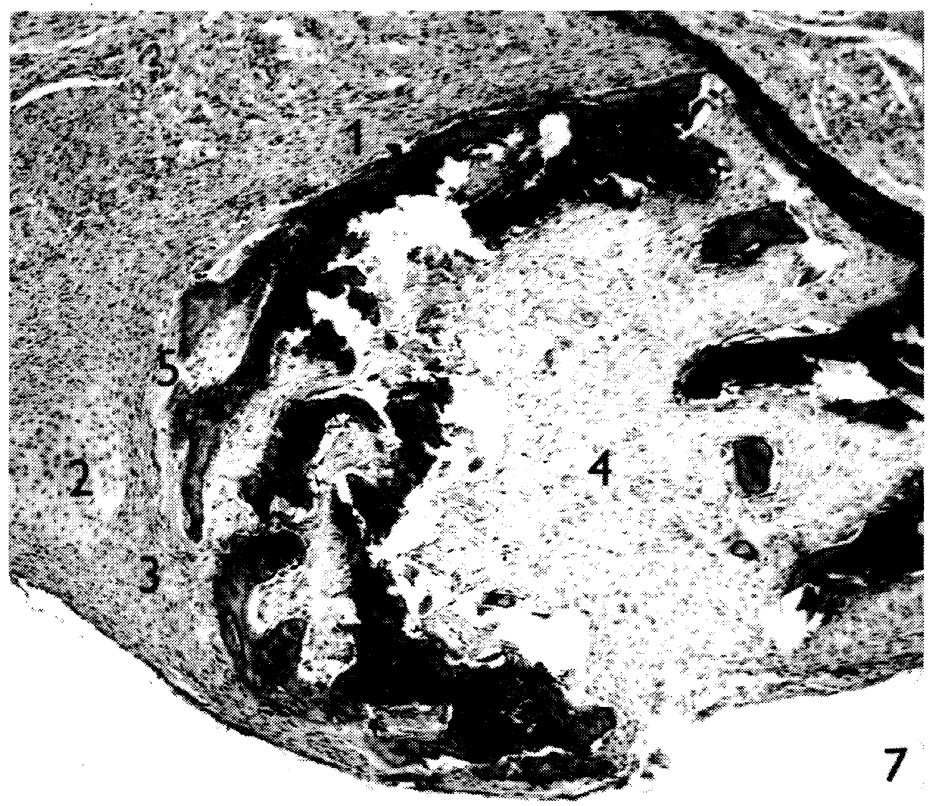

Fig. 7: Clavicle with the central cavity. x 100. 1 - fibrous surface layer, 2 - preclavium, 3 - fibrous blastema, 4 central cavity filled with connective tissue, 5 - osteoid trabeculae with osteoblasts on the surface of the clavicle

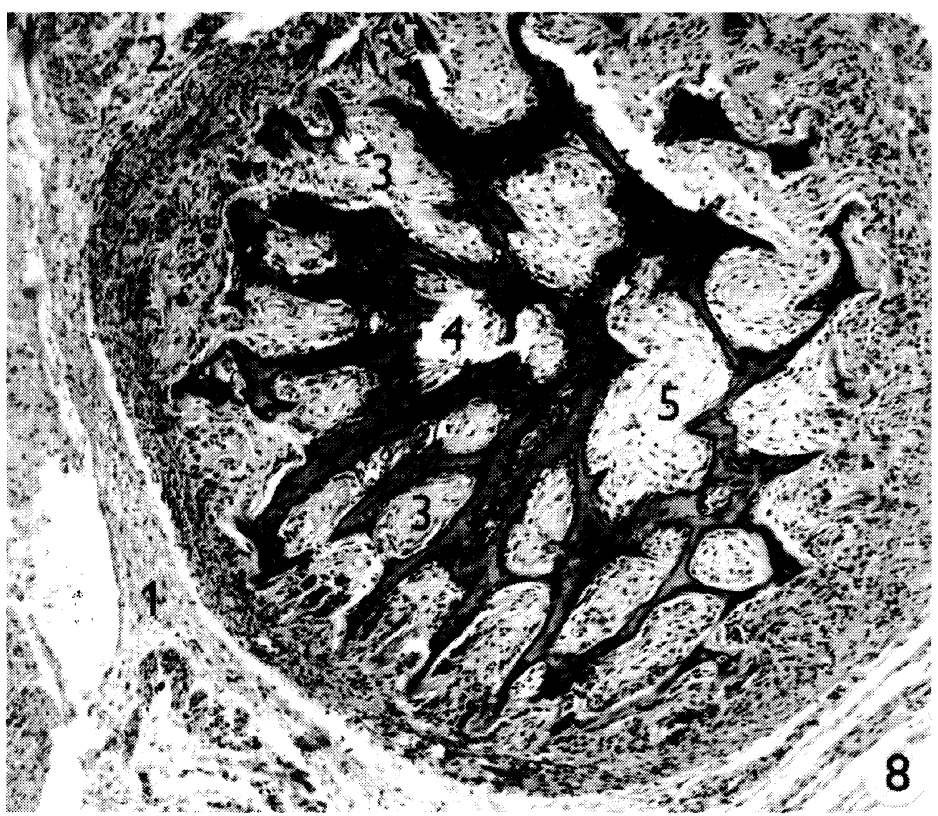

Fig. 8: Transversal section through a clavicle with trabeculae aiming radially. x 100. 1 - fibrous surface layer, 2 junction with intersectio clavicularis, 3 - intertrabecular space, 4 - developing central cavity, 5 - connective tissue of the central cavity. 